\title{
Optimization of Biogas Production from Dairy Wastewater using Upflow Anaerobic Filter (UAF) Reactor
}

\author{
S. Prithiviraj, C. Jodhi
}

\begin{abstract}
The present study explores the feasibility of biogas production from dairy wastewater in the UAF reactor with simultaneous wastewater treatment. The study was carried out at different hydraulic retention times $(8 \mathrm{~h}, 12 \mathrm{~h}, 16 \mathrm{~h}, 24 \mathrm{~h})$. Two different media such as pebble stone media and aggregate media were used as the packed media. The maximum COD removal efficiency of $91.55 \%$ is achieved at the hydraulic retention time of 24 Hours with an organic loading rate of $1.35 \mathrm{~kg} / \mathrm{m}^{3} / \mathrm{d}$ for aggregate media, whereas for pebble stone media a maximum COD removal efficiency of $76.32 \%$ is achieved. Before the start of the experiments, the COD/BOD ratio is fixed to 1.4 with initial COD and BOD of $1350 \mathrm{mg} / \mathrm{L}$ and $960 \mathrm{mg} / \mathrm{L}$. So, from the results it is concluded that the Upflow Anaerobic Filter (UAF) Reactor can be used as a one of the best treatment methods for the diary wastewater treatment.
\end{abstract}

Keywords: Biochemical oxygen demand, Chemical Oxygen demand, Dairy Wastewater, Packed media, UAF Reactor.

\section{INTRODUCTION}

Water pollution is an emerging problem in the modern world due to the rapid use of water in industries for manufacturing and other purposes [1]. These pollutions are causing serious issues to the environment and in turn, affect the surface water and groundwater. Even a very less quantity of pollutants say 1 $\mathrm{mg} / \mathrm{L}$ will also result in degradation of aquatic life in the ecosystem [2]. If these pollutants are not treated properly it will cause adverse effects to the environment and to our ecosystem. Even though the government is taking many initiatives to treat the wastewater, but the present treatment technologies can't completely treat the wastewater generation from industries. Treatment methods are generally classified as physical-chemical and biological methods [3]. Of these different treatment methods, biological methods are having many advantages than physical and chemical methods [4-5]. Since biological methods are cost-effective and by-products

Revised Manuscript Received on April 18, 2020.

* Correspondence Author

S. Prithiviraj *, PG Students, Environmental Engineering, Department of Civil Engineering, Annamalai University, Tamil Nadu, India Email: prithivraj151@gmail.com

C. Jodhi, Associate Professor, Department of Civil Engineering, Annamalai University, Tamil Nadu, India. Email: jee.ezhiljodhi@gmail.com

(c) The Authors. Published by Blue Eyes Intelligence Engineering and Sciences Publication (BEIESP). This is an open access article under the CC BY-NC-ND license (http://creativecommons.org/licenses/by-nc-nd/4.0/) can be obtained at the end of the treatment and it will be additional revenue for the treatment and will result in a reduction of cost for the treatment process. Biogas production is one of the best by-products that can be obtained from the wastewater in the anaerobic digestion tank at optimum hydraulic retention time and organic loading rate [6-7]. So nowadays all the treatment is enhanced with the anaerobic digestion tank for the sludge treatment and from these sludges, biogas is produced in a larger amount. Recently from the biogas, it possible to generate electricity also. So, this anaerobic digestion tank will be the economical treatment method for sludge and wastewater treatment. Of the different industries, the dairy industry is one of the fastest emerging industries in all countries due to the dairy products that are used in day to day activities.to meet the demand of the dairy products advancements has been evolved in veterinary science for the milk production Of all the nations, India is one among the top milk producers and dairy products are produced in huge quantity This has created a serious issue to the environment due to the generation of huge quantity of wastewater. It is also estimated that approximately 0.2 to 10 liters of wastewater are generated per liter of milk is processed the primary source for the generation of wastewater is from cleaning and washing of processing plants Dairy industry wastewater are classified into two groups. The first is concerned with high flowrates and second is dealing with small milk transformation units. Due to this highly polluted wastewater, industries are not having the capacity to treat the wastewater and result in a direct discharge into the environment. Biogas can be produced by dark fermentation of the photo fermentation process [8-9]. But biogas production is maximum at thermophilic conditions. [10]. The current investigation deals with the treatment of dairy wastewater in an up-flow anaerobic filter reactor for the biogas production using different media as a packing material.

\section{MATERILAS AND METHODS}

\section{A. Upflow Anaerobic Filter}

Upflow Anaerobic Filter (UAF) reactor made of polyvinyl chloride (PVC) was used in the present study. The reactor had an internal diameter of $10 \mathrm{~cm}$ and a height of $75 \mathrm{~cm}$ resulting in a total volume of 5.890 liters and a bed volume of 3.53 liter. A gas headspace of $15 \mathrm{~cm}$ was provided on the top of the reactor. Pebble stone and aggregated stone are used as a media.

\section{Published By:}

Blue Eyes Intelligence Engineering \& Sciences Publication

(C) Copyright: All rights reserved. 
A schematic view of the upflow anaerobic filter reactor is shown in Fig. 1.

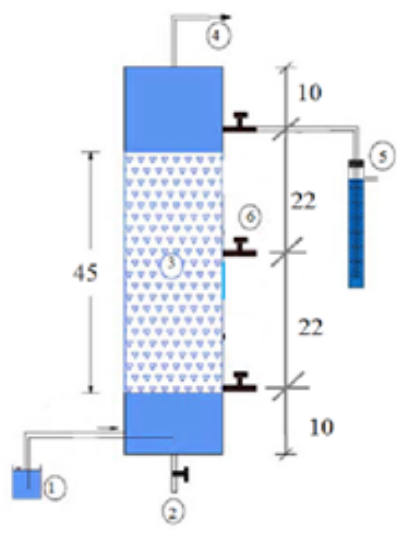

1. INFLUENT TANK

2. SLUDGE OUTLET

3. PEBBLE STONE AND

AGGREGATE MEDIA

4. GAS COLLECTION

5. EFFLUENT OUTLET

6. SAMPLING PORT

Figure 1: Schematic arrangement of Upflow Anaerobic Filter (UAF) reactor

\section{B. Substrate}

Dairy wastewater generated from Aavin plant, Perur, Coimbatore, Tamil Nadu was used as the substrate. Initially, the reactor was fed with the wastewater collected from the dairy industry (Aavin). From the third week onwards, the feed was prepared by dilution of milk with tap water and the addition of alkalinity and nutrients dilution made with respect to the initial characteristics of the wastewater collected from AAVIN. Characteristics of the wastewater are summarized in Table1.

Table 1: Initial Characteristics of. Dairy Wastewater from Aavin and Synthetic Dairy Wastewater

\begin{tabular}{|c|l|l|l|}
\hline S.No. & Characteristics & $\begin{array}{l}\text { Dairy } \\
\text { Wastewater } \\
\text { from Aavin }\end{array}$ & $\begin{array}{l}\text { Synthetic } \\
\text { Dairy } \\
\text { Wastewater }\end{array}$ \\
\hline 1. & $\mathrm{pH}$ & $7.1-7.4$ & 1120 \\
\hline 2. & $\begin{array}{l}\text { Total solids } \\
\text { (mg/L) }\end{array}$ & 1359 & 712 \\
\hline 3. & $\begin{array}{l}\text { Total dissolved } \\
\text { solids (mg/L) }\end{array}$ & 720 & 1123 \\
\hline 4. & $\begin{array}{l}\text { Total volatile } \\
\text { solids (mg/L) }\end{array}$ & 1040 & 1560 \\
\hline 5. & $\begin{array}{l}\text { Total COD } \\
\text { (mg/L) }\end{array}$ & 1350 & 1020 \\
\hline 6. & BOD (mg/L) & 960 & 1009 \\
\hline 7 & $\begin{array}{l}\text { Volatile } \\
\text { solids(mg/L) }\end{array}$ & 988 & 515 \\
\hline 8. & $\begin{array}{l}\text { Alkalinity (mg/l } \\
\text { as CaCO ) }\end{array}$ & 710 & 650 \\
\hline
\end{tabular}

\section{Seeding And Operating Conditions}

Effective microorganisms were used as seed and the reactor was seeded anaerobically with stale cow dunk. The wastewater collected from aavin stored in a cold room at $40^{\circ} \mathrm{C}$ to reduce degradation during storage. Room temperature is maintained as an optimum temperature for various operational conditions. Hence the methanogenic population is maintained due to tropical and sub-tropical climate. The operating temperature of the reactors was in the mesophilic range $\left(29-35^{\circ} \mathrm{C}\right)$. The operating conditions maintained for the anaerobic filters were as follows, $\mathrm{pH}$ of 6.8 to 7.2, Temperature of $30^{\circ} \mathrm{C}$ and HRTs at 24 h, 16 h, 12 h, and $8 \mathrm{~h}$.

\section{Biogas Outlet}

The biogas outlet was provided at the top of the reactor (Fig. 2). A gas headspace of $15 \mathrm{~cm}$ was maintained. Biogas produced from the reactor was collected in a gas collection unit.

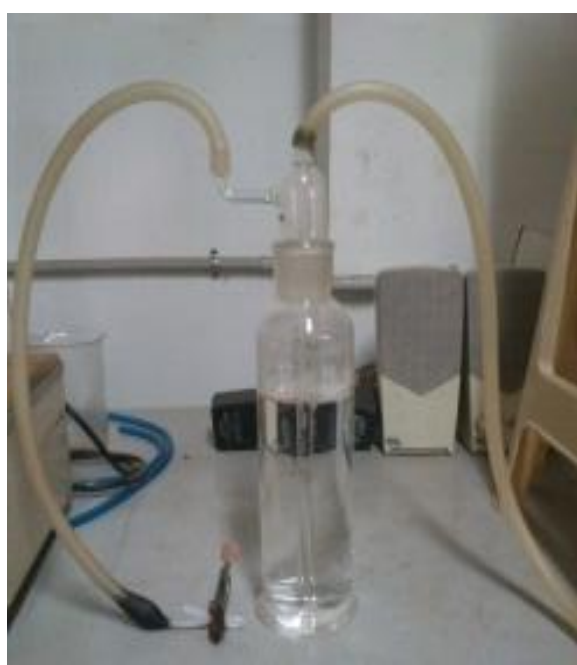

Figure 2: Gas Collection Jar

\section{E. Operation Of Uaf Reactor}

\section{Phase 1}

Initially, the reactor was fed with OLR of $1.35 \mathrm{~kg}$ $\mathrm{COD} / \mathrm{m}^{3} / \mathrm{d}$ operated for an HRT of $24 \mathrm{~h}$ with a constant flow rate of $3.53 \mathrm{~L} / \mathrm{d}$ and an inlet COD of $1350 \mathrm{mg} / \mathrm{L}$ with an up-flow velocity of $0.60 \mathrm{~m} / \mathrm{s}$. The above operational condition was maintained in the reactor for four days after the steady-state has been reached. Samples were collected from the UAF reactor port 1 for the consecutive four days. The reactor attains a steady-state within 3 days from the start-up of phase 1 operation. Further, the OLR was increased with an increase in the inlet COD for HRT of $24 \mathrm{~h}$.

\section{Phase 2}

The reactor was fed with OLR of $2.04 \mathrm{~kg} \mathrm{COD} / \mathrm{m}^{3} / \mathrm{d}$ operated for an HRT of $16 \mathrm{~h}$ with a constant flow rate of 5.348 $\mathrm{L} / \mathrm{d}$ and an inlet COD of $1350 \mathrm{mg} / \mathrm{L}$ with an up-flow velocity of $0.98 \mathrm{~m} / \mathrm{s}$. The reactor attains a steady-state within 4 days from the start-up of phase 2 operation. The above operational condition was maintained in the reactor for four days after the steady-state has been reached. Samples were collected from the UAF reactor port 1 for the consecutive four days.

\section{Phase 3}

The reactor was fed with OLR of $2.70 \mathrm{~kg} \mathrm{COD} / \mathrm{m}^{3} / \mathrm{d}$ operated for an HRT of $12 \mathrm{~h}$ with a constant flow rate of $7.06 \mathrm{~L} / \mathrm{d}$ and an inlet COD of $1350 \mathrm{mg} / \mathrm{L}$ with an up-flow velocity of $1.20 \mathrm{~m} / \mathrm{s}$. The reactor attains a steady-state within 6 days from the start-up of phase 3 operation. The above operational condition was maintained in the reactor for four days after the steady-state has been reached. Samples were collected from the UAF reactor port 1 for the consecutive four days.

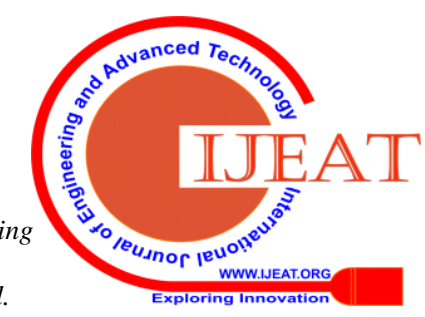




\section{Phase 4}

The reactor was fed with OLR of $4.08 \mathrm{~kg} \mathrm{COD} / \mathrm{m}^{3} / \mathrm{d}$ operated for an HRT of $8 \mathrm{~h}$ with a constant flow rate of 10.696 $\mathrm{L} / \mathrm{d}$ and an inlet COD of $1350 \mathrm{mg} / \mathrm{L}$ with an up-flow velocity of $1.80 \mathrm{~m} / \mathrm{s}$. The reactor attains a steady-state within 9 days from the start-up of phase 4 operation. The above operational condition was maintained in the reactor for four days after the steady-state has been reached. Samples were collected from the UAF reactor port 1 for the consecutive four days. The determination of COD, BOD, Total Solid, Total Dissolved solid, Total Suspended Solid and $\mathrm{pH}$ were tested in accordance with the Standard Methods listed for water \& wastewater.

\section{RESULTS AND DISCUSSION}

\section{A.Cod Removal Efficiency}

Maximum COD removal efficiency of $76.72 \%$ for pebble stone media and $91.55 \%$ for aggregate was achieved at an OLR of $1.35 \mathrm{~kg} \mathrm{COD} / \mathrm{m}^{3} / \mathrm{d}$ for HRT of $24 \mathrm{~h}$. The removal efficiency for $8 \mathrm{~h}$ HRT is about $45.03 \%$ and $78.88 \%$ due to the loss of biomass during washout had reduced the COD removal efficiency (Fig. 3 and 4). During the stepped increase of OLR, COD removal efficiencies were gradually increased. This was in general agreement with COD removal efficiencies were increased with time of operation. There is only a $10 \%$ reduction in efficiency between HRT $16 \mathrm{~h}$ and HRT $12 \mathrm{~h}$. The reason for the lower removal efficiency could be due to the higher organic loading rate at shorter HRT.

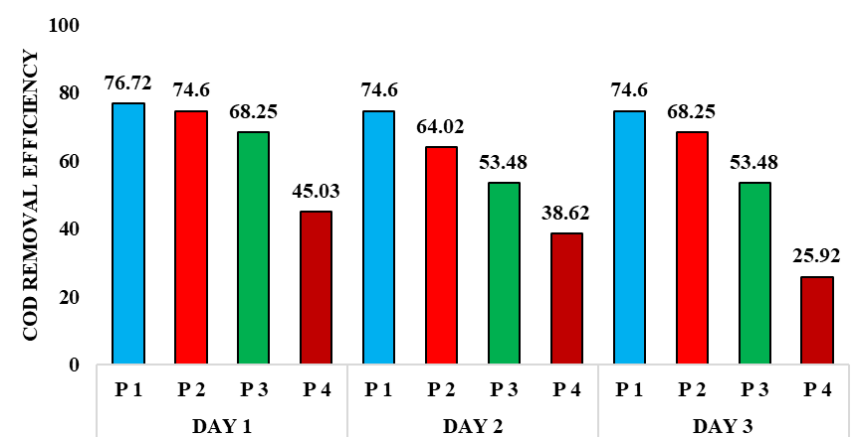

Figure 3: COD removal efficiency for pebble stone as a packing media.

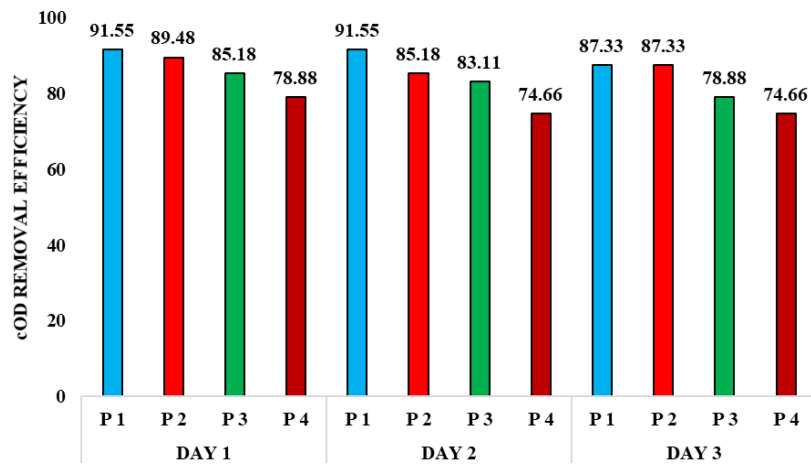

Figure 4: COD removal efficiency for aggregate stone as a packing media.

\section{B.Bod5 Removal Efficiency}

The maximum BOD removal efficiency of $76.61 \%$ for Pebble Stone Media and 91.56\% for aggregate media was achieved for 24 HRT (Fig. 5 and 6). The COD/BOD ratio was fixed to 1.4. when the HRT is reduced to $8 \mathrm{H}$, the removal efficiency of only $44.72 \%$ is achieved. The decrease in HRT results in a decrease in removal efficiency. From the batch study, it is concluded that there is not much difference with respect to the HRT of 24 hours and 16 hours.

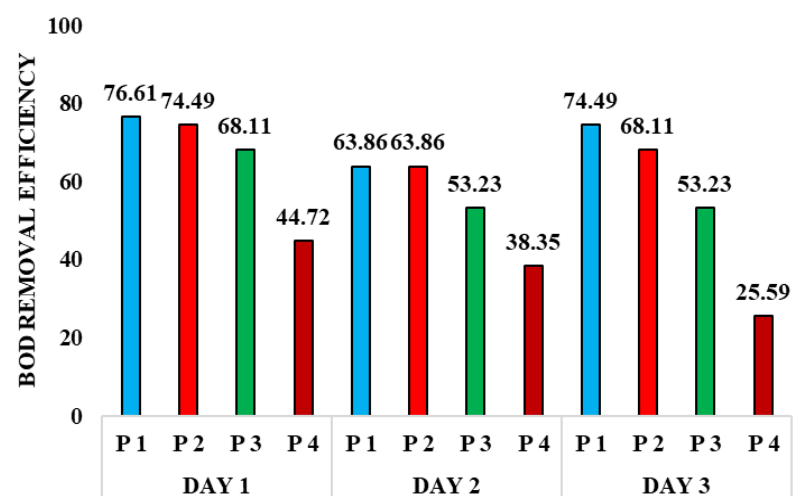

Figure 5: BOD removal efficiency for pebble stone as a packing media.

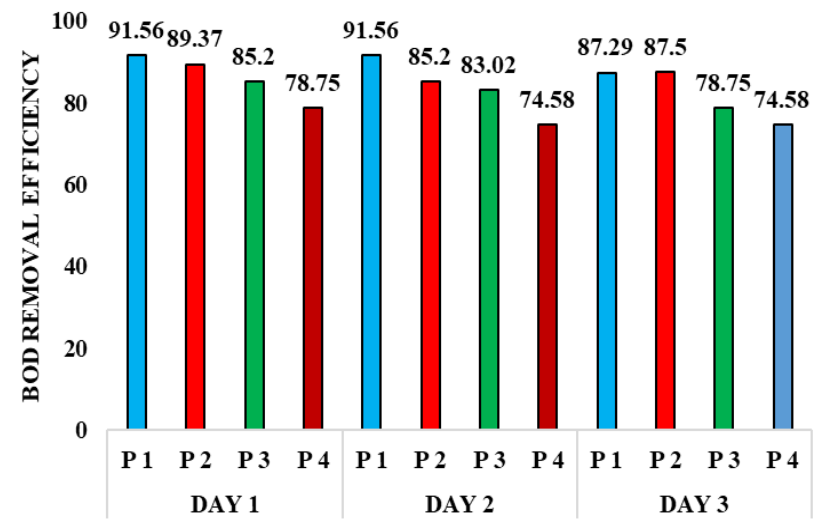

Figure 6: BOD removal efficiency for aggregate stone as a packing media.

\section{C.Total Solids Removal}

Anaerobic bacteria are slower growing microorganisms compared with the aerobic bacteria. Moreover, methanogenic bacteria are slower growing bacteria compared with the acid-forming bacteria. Therefore, HRT of more than 1 day was applied during the initial start-up of UAFs for about 38 days to facilitate methanogenic bacteria to form a biofilm.

Solids removal efficiency can be affected by temperature, organic loading rate (OLR), hydraulic retention time (HRT) and flow velocity. Under 24 HRT, the effluent TS concentrations ranged from 176 to $232 \mathrm{mg} / \mathrm{L}$ and the effluent SS concentrations ranged from 137.6 to $187.2 \mathrm{mg} / \mathrm{L}$. The SS concentration was very low during $24 \mathrm{~h}$ HRT but during $12 \mathrm{~h}$ and $8 \mathrm{~h}$ HRT higher concentration was observed. The reasons for this could be higher hydraulic loading rate would have sloughed off the attached biofilm and higher organic loading would have increased the suspended biomass concentration. The maximum removal of solids was observed during $24 \mathrm{~h}$ HRT. The concentration of solids in the treated effluent for varied OLR $\mathrm{kg} \mathrm{COD} / \mathrm{m}^{3} / \mathrm{d}$ is given in table 2 .
Published By:

Blue Eyes Intelligence Engineering \& Sciences Publication

(C) Copyright: All rights reserved.

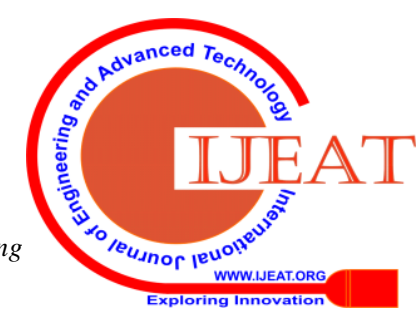


Table 2: Solids concentration in the effluent for varied OLR at HRT 24, 16, 12 and $8 \mathrm{~h}$ respectively.

\begin{tabular}{|c|c|c|c|c|}
\hline \multirow[t]{2}{*}{ Phases } & \multirow[t]{2}{*}{ Parameter } & \multicolumn{3}{|l|}{ Day } \\
\hline & & Day1 & Day2 & Day3 \\
\hline \multirow[t]{3}{*}{$\begin{array}{c}\text { PHASE } 1 \\
\text { (HRT 24h) }\end{array}$} & TS mg/L & $\begin{array}{l}205 . \\
2\end{array}$ & 49.2 & 156 \\
\hline & TDS mg/L & 232 & 44.8 & $\begin{array}{l}187 . \\
2\end{array}$ \\
\hline & TSS mg/L & 176 & 38.4 & $\begin{array}{l}137 . \\
6\end{array}$ \\
\hline \multirow[t]{3}{*}{$\begin{array}{c}\text { PHASE } 2 \\
\text { (HRT 16h) }\end{array}$} & TS mg/L & $\begin{array}{l}212 . \\
8 \\
\end{array}$ & 33.2 & $\begin{array}{l}179 . \\
6 \\
\end{array}$ \\
\hline & TDS mg/L & $\begin{array}{l}234 . \\
8 \\
\end{array}$ & $\begin{array}{l}109 . \\
2\end{array}$ & $\begin{array}{l}125 . \\
6\end{array}$ \\
\hline & TSS mg/L & $\begin{array}{l}366 . \\
4\end{array}$ & 16 & 350 \\
\hline \multirow[t]{3}{*}{$\begin{array}{c}\text { PHASE } 3 \\
\text { (HRT 12h) }\end{array}$} & $\mathrm{TS} \mathrm{mg} / \mathrm{L}$ & $\begin{array}{l}459 . \\
6\end{array}$ & $\begin{array}{l}107 . \\
6\end{array}$ & 352 \\
\hline & TDS mg/L & $\begin{array}{l}216 . \\
4\end{array}$ & 52.8 & $\begin{array}{l}163 . \\
6\end{array}$ \\
\hline & TSS mg/L & $\begin{array}{l}226 . \\
4\end{array}$ & $\begin{array}{l}102 . \\
4\end{array}$ & 124 \\
\hline \multirow[t]{3}{*}{$\begin{array}{l}\text { PHASE } 4 \\
\text { (HRT 8h) }\end{array}$} & TS mg/L & $\begin{array}{l}216 . \\
4 \\
\end{array}$ & 61.2 & $\begin{array}{l}155 . \\
2 \\
\end{array}$ \\
\hline & TDS mg/L & 184 & 62.8 & $\begin{array}{l}121 . \\
2\end{array}$ \\
\hline & TSS mg/L & 384 & 48 & 336 \\
\hline
\end{tabular}

\section{CONCLUSION}

The result obtained from the present study concludes that the application of the UAF reactor of hybrid type can successfully treat dairy wastewater at mesophilic temperatures. From the performance evaluation of UAF reactor the following conclusions were drawn:

- A start-up period of 38 days was required to achieve the steady-state phase with an OLR of $0.89 \mathrm{~kg}$ $\mathrm{COD} / \mathrm{m}^{3} \mathrm{~d}$ at an HRT of $36 \mathrm{~h}$.

- The results show that the anaerobic filter performance at different HRTs in terms of $\mathrm{BOD}_{5}$ and COD removal did not differ significantly.

- $\quad$ The UAF performed similarly at 24 hours and 16 hours fluctuating HRT in terms of the solids, COD and $\mathrm{BOD}_{5}$ removal.

- Moreover, the effluent quality achieved was very close to minimal standards for the discharge of effluents from the dairy industry.

- UAF reactor with low flow velocity has been feasible for treating dairy wastewaters in warmer climates resulting in lower energy requirements and less sludge production.

\section{REFERENCES}

1. R. Gokulan, G. Ganesh Prabhu, J. Jegan and A. Avinash, "A Critical Insight into Biomass Derived Biosorbent for Bioremediation of Dyes Chemistryselect. 4 (34), 9762-9775. (2019).

2. R. Gokulan, G. Ganesh Prabhu and J. Jegan, “A novel sorbent Ulva lactuca-derived biochar for remediation Remazol brilliant orange 3R in packed column" Water Environ. Res. 91 (7), 642-649 (2019)

3. R. Gokulan, A. Avinash, G. GaneshPrabhu and J. Jegan, "Remediation of remazol dyes by biochar derived from Caulerpa Scalpelliformis - An eco-friendly approach “, J. Environ. Chem. Eng. 7 (5), 103297 (2019).

4. R. Gokulan J. Raja Murugadoss J. Jegan and A. Avinash, "Comparative Desorption Studies on Remediation of Remazol Dyes Using Biochar (Sorbent) Derived from Green Marine Seaweeds", ChemistrySelect. 4(25), 7437-7445. (2019).

5. R. Gokulan, G. GaneshPrabhu, and J. Jegan, "Remediation of complex remazol effluent using biochar derived from green seaweed biomass", Int. J. Phytoremediat. 21(12),1179-1189. (2019).

6. R. Gokulan and N. Mohankumar, "Optimization of Conditions for Bio hydrogen Production from Industrial Waste by Anaerobic Co-digestion", Nature Environment and Pollution Technology, Vol 13(4), 791-794 (2014)

7. R. Gokulan, G. Ganesh Prabhu, J. Raja Murugadoss and S Hariharasuthan, "Optimization of bio-hydrogen production from biowastes”, Eco. Env. \& Cons. 24 (1) 284-287, (2018)

P.C. Hallenbeck and D. Ghosh, "Advances in fermentative biohydrogen production: the way forward?”, Trends Biotechnol. 27, 287-297 (2009). and limitations to practical application “, Int J Hydrogen Energy. 29, 173-185 (2004)

Y.T. Chen, N. Yu , Z. Y. Sun, M. Gou, Z. T. Xia, Y. Q. Tang, and K. Kida, "Acclimation Improves Methane Production from Molasses Performance and Microbial Community Dynamics”, Appl. Biochem. Biotechnol. doi:10.1007/s12010-020-03236-7. (2020).

\section{AUTHORS PROFILE}

Mr. S. Prithiviraj currently pursing his post graduate degree in Environmental engineering from department of Civil Engineering, Annamalai University. He completed is undergraduate degree in Civil Engineering from Annamalai University. His area of interest includes, biogas production, dark and photo fermentation, digestion tank, wastewater treatment. He published 4 national journals and presented 5 research papers in international conference.

Dr. C. Jodhi currently serving as a Associate professor in the Department of Civil Engineering. He obtained his Bachelor's degree in Civil and Structural Engineering in 1994, Master's Degree in Environmental Engineering in 1996 and Doctoral degree in Civil Engineering in 2012 from Annamalai University. He has a number of National and international journals to his credit. His areas of interest include wastewater treatment, Air pollution and Solid waste management. 